\title{
"Imagine All the People, Sharing. .." or A (Not So) Modest Proposal Made on the Eve of IDEA Reauthorization
}

\author{
Nina Zuna and Rud Turnbull \\ University of Kansas \\ Beach Center on Disability
}

The authors present a brief commentary and analysis of two problems related to 30 years of IDEA implementation: an increasing schism between general education and special education, and the unequal treatment of an entire class of students. Over the years, special education has become its own microcosm of programs and practices, making it difficult to realize an interdisciplinary approach to the education of all students. The authors analyze the possible sociopsychological implications of the categorization of students. They end with their vision of the unification of general education and special education into one education system for all students.

DESCRIPTORS: educational reform, racially integrated, separatism

From whom should we take our cues as Congress considers the reauthorization of IDEA (1997)? From John Lennon, imagining that all the students share the schools together? Or from Jonathan Swift (1729), author of Gulliver's Travels and the Dean of St. Paul's Cathedral, London, who made an audacious and ironic proposal that the best way to cure hunger in Ireland would be to cannibalize infants, thereby reducing the number of people who clamor for food while simultaneously feeding those who are older and stronger and presumptively more valuable to society than a newborn? Why not take our cues from both, and, in a Swiftian spirit of frontal challenges to convention, make a proposal that, Lennon-like, imagines what Congress might have done in 1975 and should do in 2004?

To begin, let us consider the educational, economic, cultural, and societal implications of IDEA. In a Swiftian spirit of audacity, let us boldly challenge our contemporaries and the system that IDEA created-a system that creates inherently unequal treatment and opportunity even while advocating for equal treatment and opportunity, a system that can be unintentionally

Address all correspondence and requests for reprints to Nina Zuna, University of Kansas, Beach Center on Disability, 1200 Sunnyside Ave., Haworth Hall, Rm. 3123, Lawrence, KS 66045. E-mail: nzuna@ku.edu maleficent even while purporting to be beneficent. And, Lennon-like, let us share a vision for new education policy and practice for all children. Yes, all. What don't we understand about that simple word "all"?

\section{Problem 1: The Division of General Education and Special Education}

No doubt, Congress was right to address the dismal and discriminatory treatment of school-aged students when, in 1975, it enacted IDEA's predecessor law. In retrospect, perhaps our actions were wrong. Perhaps the law and we who advocated for the original law (and its creation of a separate set of rights restricted to students with disabilities) erred grievously in the choice of means. Rather than adopting a universal approach to educating students with disabilities by creating equal rights for both them and students who do not have disabilities, Congress with our approval enacted a separatist, segregating, exceptionalistic approach. In a sense, this decision led to the further separation of children: within the walls of their school, their community, and later as adults, isolates within mainstream society.

The 1975 law was a powerful victory for children with disabilities and their families, and perhaps it was all we as a nation and the children's advocates knew to do at the time, but that law marked the beginning of the formal line of demarcation between general education and special education. It took more than a decade for parents and educators to challenge the separate environments in which their children were educated, to move beyond the civil-rights model of integration into a human-rights model of physical and psychological inclusion, participation, and contribution. By then, however, separation of general and special education was firm. The question, "Who is responsible for the education of a child with a disability, the special educator or the general educator?" had been answered: Those who are so different should be identified and educated by those who are also so differently qualified.

Joint responsibility for the education of children with disabilities both philosophically and in practice does 
not exist, largely because the 1975 law decreed separatism. The field of special education now is hardly a single system; instead, it is a system of systems, a conglomeration of fragmented services often delivered in isolation from one another and rarely integrated within the general education environment. It is a microcosm of its own programs, research, teachers, instructional practices, and laws.

We do not wish to disparage the professionals and schools who have delivered services according to the letter and spirit of the law, because they do exist, but all is not well everywhere. Why is this so? Because in 1973-75, when IDEA was first shaped, we-special educators, lawyers, advocates of all kinds-lacked the foresight to plan for the professional practices necessary to educate all children together. For nearly three decades, many special educators and families have been fighting for and continue to fight for true equality and inclusion for their students. We can only wonder what our educational system and society would be today if, when Lennon was imagining, we had envisioned all teachers would teach all students.

\section{Problem 2: Unequal Treatment and Psychological Harm}

In his "Modest Proposal," Swift ironically argued that the proper cure for poverty is for the wealthy to eliminate the poor, literally to consume them. Is it too bold for us now to suggest that IDEA's separatist, specialized, exceptionalistic approach contributes to psychological harm and an unequal education for children with disabilities? It is as though the education system "consumes" its own.

Before 1975, children with disabilities were denied an education solely on the basis of their disabilities. Two court cases, PARC v. Pennsylvania (1972) and Mills v D. C. Board of Education (1972), creatively used the precedent of Brown v. Topeka Board of Education (1954) to apply the equal protection argument to students with disabilities. $P A R C$ and Mills legitimatized Congressional action in 1975. So far, so good. But Brown's factual predicate-separate is inherently unequal because separation teaches those who are separated that they deserve separation and are intrinsically less worthy-was not used to the extent necessary to ensure equal protection and equal opportunity for all children.

It is not enough to read Brown (Turnbull \& Turnbull, 2000) by substituting "child with disability" for "Negro," as an equal protection case alone. Read it in a more robust way, a more Swiftian/ radical way: substitute "labeling" or "classification" for "segregation," then also substitute "legally equivalent" for "racially integrated." Finally, add a statement that general education students are not labeled.
[Labeling] of children in public schools has a detrimental effect upon [children]. The impact is greater when it has the sanction of the law; for the policy of [labeling] children is usually interpreted as denoting inferiority for this group of [children]. A sense of inferiority affects the motivation of a child to learn. [Labeling] with the sanction of the law, therefore, has a tendency to retard the educational and mental development of [children] and to deprive them of some of the benefits they would receive in a [legally equivalent] educational school system that does not label. (Adapted from Turnbull \& Turnbull, 2000; Appendix A, p. 391)

Now, like Lennon, imagine what Brown would teach, how PARC and Mills might have been decided, and what IDEA might have provided. It is the very act of classification, of labeling, that justified two separate educational policies, one for children with disabilities (IDEA) and one primarily for children without disabilities (NCLB). True, in some children disability (i.e., the extent of disability) is a distinction that does and can make a difference that justifies different treatment, either by way of additional accommodations or unequal but not invidious treatment.

But with respect to so many children now classified into special education, we must return to Brown's factual predicate and ask: have we robbed, and do we continue to rob, individuals of their liberty by labeling them with a disability? Do we do a "Swift number" on them? Arguably, yes, because IDEA guarantees special education services only after a child is identified as having a disability.

It is not the evaluation for eligibility or the provision of individualized education that is the problem per se; it is the consequences that attach to evaluation-the classification and labeling that categorize, stigmatize, sort, separate, and endure. These consequences, in essence, "consume" their identity. They are no longer just children. They are now, even with our polite "person first" language, children with disabilities. These consequences are further sanctioned by an IDEA reimbursement/financing system that incentivizes labeling. What freedom does the child have not to be labeled? What messages do we, Brown-like, send? What have we taught the child? What do we teach others and ourselves in power? What powers do we acquire thereby? The most critical issue in special education, and in all disability policy, is the issue of classification. It is the beginning and end-point, the alpha and omega, of a person's life.

Imagine, then, life without a label. Imagine schools that do not label, laws that do not result in labels, and laws and systems that abjure the unequal by abjuring classification. What message would that approach convey? To the (now-labeled) students, it would say, "We refuse to cause you emotional pain, to isolate you, to 
stigmatize you, and to treat you invidiously, here and after you leave school."

To each of us, the refuse-to-label message would say that we truly understand Brown, not as (just) the (great) equal-protection case but as the great admonition against causing harm in the name of doing good, as the clear warning that we with the power to label can hurt those whom we label. The message would also be that we do not want to perpetuate two systems of education, two classes of students, and two types of citizens: those with and those without disabilities. The message would be that IDEA, for all of its power, is fundamentally flawed because, ironically, it reflects and perpetuates the very duality, the very separateness that it seeks to combat.

A refuse-to-label message would say something about us all, which is that each of us lives somewhere on a continuum of disability. None of us is so comely or handsome as to be regarded as "perfect." None of us is so bionic as to be the superman or superwoman, the super-mensch. And each of us, as ADA proclaims, must admit that disability is a natural part of the human experience and therefore, as ADA fails to say, each of us who, when "disabled," must be welcomed into society and not simply protected from discrimination (ADA, 1990). Imagine what message would come if Congress were to have said that disability is a natural experience that is to be accepted, even welcomed, and that those who are "different enough" are to be welcomed, not simply protected. That message, more than any "least restrictive" principle, would have profound implications for the social relationships of children with disabilities when they are in school and when they are not, when they are children and when they are adults.

A modest proposal might require a modest start, but let us just imagine something not so modest. Start with changing the ADA proclamation so that it no longer affirms simply a negative posture, which is that discrimination is against the nation's policy, but instead affirms a positive posture, which is that a natural condition, disability, is not only a fact of life but also a welcome fact. Consider adopting, as our national policy, Sweden's approach, which eschews regarding disability as a "characteristic of a person" and instead recognizes the consequence of having a disability: a person with a functional impairment "is confronted by an inaccessible environment" (Disability Policies in Sweden, 2000). Admit the social construct to the light of policy and, while we are at it, confess that Trilling (1980) is right: the objects of our pity have become the objects of our study and are now the objects of our coercion.

Imagine the power of reversing our policies by adopting these (im)modest proposals. Enact a single federal education law: "Free Appropriate Public Education for All." Hold every student to "high expectations." To implement that affirming posture, adopt universally de- signed curricula, train teachers to work collaboratively with each other to serve all students, stop calling some of them "general" and others "special" educators (for labeling them is deleterious to our ends, just as labeling students is), open up "resource rooms" to serve the continuum of needs of all students, and blend (or braid) the exceptionalistic funding streams with the universalistic ones. Incorporate and fund related services and supplementary aids and services in such a way that it benefits not only those students who qualify for additional services but also struggling students who may not qualify. Then, do as most families (i.e., as microcosms of society do) do: treat the member with the "disability/ impairment" as a "regular" member of the family, not as a "special" member who needs unusually solicitous attention for every minute detail of his or her life. Just accommodate, do not differentiate.

Conduct for all children - those we now call "special" and those we regard as "regular" (in the sense that "regular" education teachers instruct them in the "general curriculum")-a functional behavioral assessment when their behaviors impede their or others' learning or create unacceptable risks to health and safety, and provide positive behavioral supports to ameliorate challenging behaviors. Extend to all children (remember, "all means all") the right of "no cessation" of education.

\section{Imagining and Proposing: Some Final Words}

Our nation is becoming more and more culturally diverse every year. A "new" (ethnic) minority now outnumbers the "old" one. Our national tongue, while still an Americanized and regionalized English, is more and more polyglot every day. The decennial census form is unfairly bounded by now-outmoded classifications; it now must accommodate "mixed" and permit "mixed" to be ever-so-broadly defined. Even the term "family" is changing, because those who now identify and unify themselves as partners perform many of the functions that the (traditional) two-gender family has performed.

Disability is a natural part of life, and how we embrace it or fail to embrace it reflects our social values and shapes our societal quality of life. So, let us imagine, and more; let us start our embrace of the natural by changing the structure of our education system to match the structure of our country and our families. To do so is to change our schools, but more it is to change society. Educational reform begets societal reform. If our children are to represent the future of our society, the inclusive future we profess to want, how can we be one nation if we teach our children through two separate systems of education, and how can we give a message of "welcome" to those who face impairments if we start by excluding them?

Leaving IDEA and NCLB intact, as they are today, 
perpetuates the educational divide that we created years ago, with all of the best intentions. We all need support. But we need and benefit most when we get it jointly. Lennon teaches us to imagine. Imagine: we can be one people, one nation, not divided. Swift teaches us to be immodest: We make the not-so-modest proposal of one law. All means all, yes?

\section{References}

ADA (1990). 42 U.S.C. 12101 et seq.

Brown v. Board of Education, 347 U.S. 483 (1954).

Disability Policies in Sweden. (2000). Retrieved June 15, 2004, from http://www.socialeurope.com/onfile/country_profiles/ swedish_disabili_policy.htm

Individuals with Disabilities Education Act (IDEA). (1997). Public Law 105-17, 20 U.S.C. Secs. 1400 et seq.
Mills v. D.C. Board of Education, 348 F. Supp. 866 (D.D.C. 1972).

No Child Left Behind Act. (2001). Pub. Law. No. 107-110, 115 Stat. 1425 .

PARC v. Commonwealth, 334 F. Supp. 1257 (E.D. Pa. 1971), 343 F. Supp. 279 (E.D. Pa. 1972).

Swift, J. (1729). A modest proposal. In M. H. Abrams (Ed.), The Norton anthology of English literature, Vol. 1 (5th ed., pp. 2174-2181). New York: W. W. Norton, 1986.

Trilling, L., quoted in Rothman, D. (1980). Convenience and conscience: The asylum and its alternatives in progressive America. Boston: Little, Brown.

Turnbull, H. R., \& Turnbull, A. P. (2000). Free appropriate public education: The law and children with disabilities (6th ed.). Denver: Love Publishing.

Received: March 16, 2004

Final Acceptance: July 3, 2004

Editor in Charge: Fredda Brown

This research was supported by a grant from the National Institute on Disability and Rehabilitation Research to the Beach Center on Disability, Grant \#H133B031133. 